\title{
Från idé till organisatoriskt nätverk. Föreningslivets förändring och förtätning i Hovmantorp
}

\author{
Jessica Hansen
}

Sammandrag: Jessica Hansen disputerade $201 \mathrm{I}$ med avhandlingen "Så fixade vi Allhallen" där hon följer resursmobiliseringen i ett lokalsamhälle för att kunna bygga en allaktivitetshall. Det kapitel (kapitel 3 i boken) som vi nu publicerar som en fristående artikel fokuserar på hur själva den organisatoriska processen såg ut, hur föreningslivet i den småländska orten Hovmantorp förändrades och förtätades under resans gång, från att idén föddes 1999 till ett klubbat beslut i kommunfullmäktige i Lessebo kommun den 28 november 2005. Hansen beskriver en process där de engagerade individerna har kunnat utnyttja och bygga vidare på sina befintliga organisationstillhörigheter när de mobiliserat sina nätverk, grupperat och omgrupperat sig och skapat en helt ny organisation. Det handlar om förutsättningarna för kollektivt handlande, om hur allianser byggs och potentiellt motstånd organiseras bort.

NYCKELORD: resursmobilisering; organisationsförtätning; organisatoriskt fält; kollektivt handlande; civilt samhälle.

PUbLICERINGSHISTORIK: Utdrag (kapitel 3) ur Jessica Hansens avhandling "Så fixade vi Allhallen". Resursmobilisering och organisationsförtätning i ett lokalsambälle, Arkiv förlag 2OII.

JESSICA HANSEN är lektor i sociologi vid institutionen för samhällsstudier vid Linnéuniversitetet.

FÖRSLAG PÅ KÄLLANGIVELSE:

Hansen, Jessica (2013) "Från idé till organisatoriskt nätverk. Föreningslivets förändring och förtätning i Hovmantorp", i Arkiv. Tidskrift för sambällsanalys, nr I, s. 6I-85. DoI: http://dx.doi.org/I0.13068/2000-6217.I.3

(C) Jessica Hansen/Arkiv förlag \& tidskrift 2013 (publicerad I3 december 20I3)

Artikeln distribueras enligt en upphovsrättslicens från Creative Commons: Erkännande-Ickekommersiell-IngaBearbetningar 3.o Unported, som medger fri ickekommersiell användning och spridning i oförändrat skick så länge källan anges. 
Arkiv. Tidskrift för samhällsanalys är en sakkunniggranskad vetenskaplig tidskrift för samhällsvetenskap och historia. Samtliga artiklar publiceras fritt tillgängliga på:

www.tidskriftenarkiv.se

(beständig länk, DoI: http://dx.doi.org/IO.I3068/2000-62I7)

Den här artikeln finns tillgänglig i följande format:

PDF \& HTML: via beständig länk, DOI: http://dx.doi.org/IO.I3068/2000-62I7.I.3

EPUB: ingår i e-boksutgåva av numret, ISBN: 978 9I 79242503

TRYCK: ingår i bokutgåva av numret, ISBN: 978 9I 7924 25I O

Grafisk utformning och sidnumrering är identisk i pdf och tryck.

Samtliga artiklar i nr I (2013) nås via beständig länk, DOI: http://dx.doi.org/I0.13068/2000-6217.I

Arkiv. Tidskrift för sambällsanalys ISSN: 2000-62I7 (för elektronisk resurs)

ISSN: 2000-6225 (för tryckta nummer)

ges ut av

Stiftelsen Arkiv för främjande och spridning av samhällsvetenskaplig och historisk forskning

genom

Arkiv förlag \& tidskrift

Box 1559

SE-22I OI Lund

BESÖK: L Gråbrödersg 3 c, ipg

TEL: O46-I3 3920

ARKIV FÖRLAG: arkiv@arkiv.nu·www.arkiv.nu

TIDSKRIFTEN ARKIV: red@tidskriftenarkiv.se · www.tidskriftenarkiv.se

ANSVARIg UTGIVARE \& CHEFREDAKTÖR: Sven Hort

ADMINistrativ RedAKTÖr: David Lindberg

RedAKtörer: Paavo Bergman, Lisa Kings, Zhanna Kravchenko 


\title{
Från idé till organisatoriskt nätverk. Föreningslivets förändring och förtätning i Hovmantorp
}

\author{
JESSICA HANSEN
}

\section{Inledning}

I detta kapitel kommer avhandlingens första frågeställning att besvaras. Hur har allhallsprojektets organisatoriska process sett ut och hur kan den förklaras? Framställningen kommer att belysa hur en idés organisatoriska inramning utvecklas och förändras över tid för att slutligen anta formen av ett mellanorganisatoriskt nätverk med politiskt inflytande. Kapitlet beskriver och förklarar hur det organisatoriska fältet i Hovmantorp förändrades och förtätades i takt med att delar av dess invånare bestämde sig för att mobilisera resurser för att bygga en allaktivitetshall. Allhall i Hovets organisering och mobilisering skedde inom ett organisatoriskt fält vars organisationer föreningen har haft att förhålla sig till.

Läsaren får följa en process som tog sin start 1999 när ortens största idrottsförening Hovmantorps gymnastik och idrottsförening för första gången artikulerade sitt behov av större träningslokaler. Därefter får läsaren följa den organisatoriska processen fram till den 28 november 2005 då kommunfullmäktige i Lessebo röstade igenom ett beslut att investera 6 miljoner kr i en allaktivitetshall. Då hade det funnits en ny förening på orten sedan den 6 maj 2004. Den hade bildats med det specifika syftet att verka för tillkomsten av en allaktivitetshall. Det kommunala beslutet

Artikeln är ett utdrag (kapitel 3) ur Jessica Hansens avhandling "Så fixade vi Allhallen". Resursmobilisering och organisationsförtätning i ett lokalsambälle, Arkiv förlag 201 I. 
innebar att kommunen satsade ekonomiskt i föreningens byggprojekt. Innan detta beslut togs hade emellertid idéns organisatoriska inramning bytt form ett antal gånger under det att dess deltagare sökt olika vägar att mobilisera stöd och resurser för sitt projekt. Det är alltså denna organisatoriska utveckling som läsaren kommer att följa i föreliggande kapitel. Framställningen är begränsad i tid till att granska den förändring och förtätning av ortens organisatoriska fält som föregick kommunpolitikernas beslut att investera ekonomiskt i projektet.

I kapitlet förklarar jag hur de som organiserade sig i föreningen förhöll sig till och mobiliserade individer och redan existerande organisationer. Jag visar hur intresseallianser byggdes upp och hur potentiellt motstånd organiserades bort. Jag visar också att det inte i första hand varit fråga om att organisera ickeorganiserade individer utan att det snarare handlat om att koppla samman redan organiserade individer och deras nätverk på ett sådant sätt att nya relationer mellan organisationer och individer skapats.

\section{Individers interaktion inom, utom och mellan organisationer}

När jag i det här kapitlet beskriver projekt Allhall i Hovets organisatoriska utveckling ifrån idé till organisatoriskt nätverk, gör jag det genom att studera individers interaktion. Till min hjälp har jag Ahrne och Papakostas (2002) diskussioner om relationer mellan individer och organisationer samt Ahrnes (1994) diskussioner om interaktioners väg inom, utom och mellan organisationer. Ahrne och Papakostas (2002) menar att en stor del av människors dagliga interaktion filtreras genom organisationer. Såväl interaktionen som relationens innehåll kommer därmed också att struktureras av organisationer. Som utgångspunkt för sitt resonemang använder de Ahrnes (1994) kategorisering av interaktion utifrån var den sker i förhållande till omgivningens organisationer. De presenterar fyra olika kategorier:

- Den första kategorin är interaktion som sker inne i organisationer. Det kan till exempel vara interaktion mellan kollegor på samma arbetsplats eller interaktion mellan medlemmar inom en förening. 
- Den andra kategorin är interaktion som sker mellan organisationer, det vill säga relationer mellan individer som tillhör olika organisationer. Det kan till exempel vara vid fackliga förhandlingar då arbetsgivarorganisationer och fackliga organisationer representerar olika medlemmar. Det kan också vara två fotbollslag som möts i en match.

- Den tredje kategorin är interaktion som sker $i$ semiorganiserade fält, det vill säga relationer mellan individer där en av dem tillhör en organisation och den andre inte gör det. Det kan till exempel vara interaktion mellan en kund och en expedit i ett varuhus. Interaktionen sker i varuhuset som utgör en organisation. Expediten är en del av organisationen medan kunden inte är det.

- Den färde kategorin som beskrivs är interaktion i semiorganiserade fält eller utanför organisationer. Det kan vara relationer mellan ickeorganiserade individer som befinner sig inom en organisation till exempel i en affär eller interaktion utanför en organisation, som till exempel två vänner på promenad i skogen.

Ahrne och Papakostas använder dessa utgångspunkter för att föra en diskussion om vad organisationer gör med människors interaktion. Detta diskuterar de utifrån två olika dimensioner där den ena tar hänsyn till i vilken grad innehållet i interaktionen är explicit eller implicit och den andra till $i$ vilken grad själva relationen är långvarig eller kortvarig. Därefter tecknar de upp en rymd och ger exempel på var olika typer av interaktioner hamnar i denna utifrån de två dimensionerna och illustrerar på detta sätt vad organisering gör med individers interaktion samt vilken typ av interaktion som organiseras (Ahrne \& Papakostas 2002: 27, figur I.I).

Jag har använt samma kategorier som utgångspunkt men för ett annat syfte. Jag strukturerar min framställning utifrån om individers interaktion sker inom organisationer, mellan organisationer, i semiorganiserade fält eller utanför organisationer för att i stället visa vad individers interaktion fär för konsekvenser för relationen mellan organisationer. Jag kommer att visa hur människor, när deras interaktion tar olika vägar $\mathrm{i}$ 
förhållande till den organisatoriska omgivningen, förändrar det organisatoriska fältets sammansättning i Hovmantorp på ett sådant sätt att dess mobiliserande potential ökar.

\section{Inomorganisatorisk interaktion 1999}

Hovmantorps gymnastik och idrottsförening (HGoIF) är en idrottsförening med ca 800 medlemmar. Den består av en fotbollssektion, en innebandysektion och en bordtennissektion. Föreningen är såväl Hovmantorps som Lessebo kommuns största förening och den bedriver en omfattande barn- och ungdomsverksamhet. 1999 artikulerade föreningen första gången ett behov av fler och större träningslokaler. Orsaken var dels att bordtennissektionen vuxit ur sina träningslokaler i Hovmantorps Folkets hus källare, dels att innebandyverksamheten började känna av brist på träningstider. Föreningen föreslog kommunledningen att en idrottshall med lokaler för innebandy och bordtennis skulle byggas på Hovmantorps idrottsplats där den drev sin fotbollsverksamhet (IPI \& 2, 5 juli 2004). Även i Kosta upplevde innebandyverksamheten brist på träningsmöjligheter. Den hade svårt att få tillgång till träningstider i Lessebo sporthall vilken var den enda hall i Lessebo kommun med godkända mått för innebandyspel. Detta resulterade i en motion från Vänsterpartiets sida om att lokalfrågan för innebandyspelare i Kosta skulle lösas (Smålandsposten I2 september 2002, del B, s. 8). Från kommunens sida beslutades att göra en utredning om behovet av hallar i samtliga kommundelar och utifrån detta ta fram kostnader, prioriteringar och möjliga alternativ. Detta skulle göras som ett delprojekt i ett större arbete som handlade om att ta fram en framtidsstrategi för Lessebo kommun. Arbetet med denna fortgick under större delen av 2000. En angelägen fråga handlade om hur kommunen skulle kunna bli mer attraktiv och därmed öka sin befolkning. En av de strategier som föreslogs var att bredda fritidsutbudet för kommunens invånare genom att till exempel tillhandahålla en god tillgång på idrottshallar. ${ }^{I}$ Under den här perioden blev det sålunda tydligt för kommunens politiker att

I. Se Framtidsstrategi för Lessebo kommun. En strategi och övergripande mål för år 2010. Remissutgåva den I5 juni 2000. Beslutad av kommunstyrelsen den 9 juni 2000. 
det fanns ett önskemål om större lokaler för idrottsaktiviteter på olika håll i kommunen.

Om vi vänder fokus mot Hovmantorp och dess föreningsliv som är i centrum för denna studie så är det utmärkande för den här perioden att det var individer inom en organisation som agerade i förhållande till kommunen. Det var föreningen HGoIF som drev frågan i förhållande till kommunen som organisation.

Jag skulle ha kunnat argumentera för att det är fråga om en mellanorganisatorisk interaktion eftersom organisationen HGoIF agerar i förhållande till kommunorganisationen. Fokus för min argumentation ligger emellertid på att belysa vad som händer med det organisatoriska fältet i Hovmantorp utanför kommunorganisationen då det mobiliseras för att agera i förhållande till kommunen. Kommunen utgör den konstant kring vilken alla andra organisationer manövrerar i syfte att uppnå ett specifikt mål. Det är vad som händer med dessa organisationer i förhållande till varandra som kommer att belysas i den fortsatta framställningen. Utifrån denna synvinkel sker den inledande mobiliseringen som en interaktion inom en organisation när HGoIF:s aktiva agerar i förhållande till kommunen genom att ta fram ett ritningsförslag till en framtida idrottshall och presentera detta för kommunledningen.

\section{Mellanorganisatorisk interaktion 2002-2003}

Utredningen som skulle göras angående utbyggnad av idrottshallar runt om i kommunen kom inte igång. Under valåret 2002 flyttades "projekt idrottshall” från en organisation till en annan. Det skedde via en individ med överlappande organisatoriska tillhörigheter. Individen var sedan många år aktiv som tränare och i perioder som styrelsemedlem i HGoIF. Samma individ var också aktiv i det lokala Centerpartiet. Den 22 april 2002 placerade han åter frågan om en idrottshall i Hovmantorp på den politiska dagordningen. Med sitt partis godkännande lade han fram en motion "angående lokaler till fritidverksamhet i Hovmantorp". I motionen föreslog han att kommunledningen skulle utreda möjligheten för Lessebo kommun att medverka till att lösa lokalbristen för fritidsverksamhet i Hovmantorp (Dnr 2002.I70-82). I och med detta 
kom en ny organisation att driva frågan om en idrottshall i förhållande till kommunen.

När motionen varit på beredning i tre månader återupptog HGoIF engagemanget för idén. Sista helgen i juni 2002 var det karneval i Hovmantorp, ett evenemang som återkommer vart fjärde år. Ett stående inslag i denna är karnevalståget med ekipage av skilda slag. Detta år deltog HGoIF i tåget och protesterade mot lokalbrist för sina aktiva medlemmar. Under augusti och september månad gjorde föreningen också en namninsamling med 800 underskrifter till stöd för en idrottshall i Hovmantorp (Smålandsposten 24 september 2002, del A, s. I8). Under augusti månad kröp valet allt närmare och i Lessebo gjorde Socialdemokraterna ett utspel. I deras valprogram hette det att de "vill arbeta för avgiftsfri förskola med bra kvalitet". Inom fyra år sa partiet sig vilja uppnå detta vallöfte som motiverades dels med att barnomsorg är en rättighet precis som skolan och därför bör vara avgiftsfri, dels med att avgiftsfrihet skulle kunna bromsa utflyttningen från kommunen (Smålandsposten 23 augusti 2002, del A, s. 26). Detta initiativ tog en oväntad vändning när ett antal artiklar med budskapet att många i Hovmantorp föredrog bättre tillgång på sporthallar framför gratis barnomsorg dök upp i den lokala dagstidningen Smålandsposten. I september publicerade denna tidning sex artiklar på temat lokalbrist i Hovmantorp och idrottshallar kom att bli en valfråga. ${ }^{2}$ Under den här perioden var det två organisationer som agerade gentemot kommunen i frågan om en idrottshall i Hovmantorp.

Som en reaktion på namnunderskrifterna och tidningsartiklarna bjöd kommunalrådet $(S)$ in representanter från samtliga idrottsföreningar och företag i kommunen till ett möte den 24 september 2002 för att diskutera framtidsfrågor på temat "vad är viktigt för att utveckla Lessebo kommun?" Mötet resulterade i att kommunchefen fick i uppgift att göra en utredning av lokalbehovet för fritidsaktiviteter i hela kommunen (Smålandsposten 25 september 2002, del B, s. 6).

Den II oktober 2002 färdigställde kommunchefen ett yttrande angående Centerpartiets motion. I yttrandet konstaterades det att det inte fanns tider tillgängliga i Hovmantorps gymnastiksal och att det också rådde brist på tider $\mathrm{i}$ Lessebo sporthall. Kostnaden för att bygga en

2. Smålandsposten 5, 6, II, I2, 24 och 25 september 2002. 
idrottshall med plats för innebandy uppskattades till mellan 9 och I2,2 miljoner kr. Den summan ställdes mot investeringsutrymmet för hela kommunens verksamhet vilken under den här perioden uppgick till I4 miljoner kr. I yttrandet hänvisades också till diskussionerna som förts på framtidsmötet där idrottsföreningar och företagare i kommunen deltagit. I dessa diskussioner hade det påtalats att det $\mathrm{i}$ andra kommuner hade byggts hallar till en kostnad av 6 miljoner kr med hjälp av företags- och föreningsengagemang. Kommunchefen föreslog att kommunfullmäktige skulle rösta igenom en investeringsbudget för 2003 och en plan för 2004 där 300 ooo kr budgeterades till projektering av en idrottshall under 2003 och att 6 miljoner kr budgeterades för investering i en idrottshall under 2004. Den 25 november 2002 röstades investeringsplanen igenom i kommunfullmäktige (Plan för framtida utbyggnad av idrottsanläggningar, KF 25 november 2002, investeringsbudget/plan 2003-2006 Lessebo kommun; Yttrande till Kommunstyrelsen över centerpartiets motion angående lokaler till fritidsverksambet i Hovmantorp).

Vad var det som hände under den här perioden? Projektet flyttade från en organisation till en annan via en person med överlappande organisatoriska tillhörigheter. Denna person åstadkom en mellanorganisatorisk interaktion som resulterade i att två organisationer kom att arbeta för samma mål i förhållande till kommunen. Resultatet av organisationernas interaktion i förhållande till varandra och till kommunorganisationen blev att en resurs motsvarande 6,3 miljoner $\mathrm{kr}$ skapades inom den kommunala organisationen. Trots detta blev det ingen idrottshall. Varför inte?

\section{Inomorganisatorisk interaktion. "Stålbadsanalys" och nya förutsättningar 2003}

När idrottshallen blivit budgeterad i investeringsbudgeten verkade saken klar. "Projekt idrottshall" hade flyttats till den kommunala organisationen och skulle nu hanteras som en kommunal angelägenhet. Parallellt med detta hade dock några andra saker skett. Under budgetarbetet

3. Redogörelsen i detta avsnitt bygger förutom protokoll också på observationsanteckningar JH/OB 29 april 2004; $\mathrm{IP}_{3} 24$ augusti 2004. 
2002 stod det klart att kommunens socialnämnd drogs med kraftiga underskott.

Den I april 2003 gav kommunstyrelsens arbetsutskott kommunchefen i uppgift att genomlysa all kommunal verksamhet (AU I april 2003). Den Io juni 2003 beslutade kommunstyrelsen att tillsätta en konsult för att dels analysera den kommunala verksamheten, dels föreslå åtgärder för att minska den kommunala verksamhetens kostnader (KS Io juni 2003). Bakgrunden var att upplåningsbehovet för den kommunala verksamheten som helhet ökat under året och beräknades uppgå till 76,5 miljoner kr för 2004 (KF I5 december 2003) att jämföras med 23 miljoner kr 2003 (KF 25 november 2002). Konsultens uppdrag kom att gå under benämningen "stålbadsanalys". Den I4 november 2003 var konsultens slutrapport klar. I rapporten fanns åtgärder som skulle minska kommunens kostnader med 44 miljoner $\mathrm{kr}$ (KF is december 2003). Som en del av dessa besparingsförslag fick politikerna rådet att stoppa den planerade investeringen i en sporthall. Denna åtgärd skulle bespara den kommunala driftsbudgeten en årligt återkommande driftskostnad motsvarande $\mathrm{i}, 5$ miljoner kr.

Kommunens ansträngda ekonomiska situation var inte okänd för kommuninvånarna. Den 2 december 2003 informerades kommunstyrelsen om att en protestlista med I 500 namnunderskrifter hade överlämnats till kommunalrådet och ordföranden i socialnämnden. I skrivelsen protesterade kommuninvånare mot nedskärningar inom den kommunala verksamheten (KS 2 december 2003). Socialnämnden hade under året arbetat fram ett besparingsförslag som innebar att kostnaderna skulle minskas med $\mathrm{I} 2$ miljoner kr under åren 2004-2006. Den största neddragningen skulle ske inom äldreomsorgens verksamhet (SN 27 augusti 2003). Den Is december 2003 var det dags att fastställa en ny investeringsbudget för kommande år det vill säga för 2004. Någon projektering av idrottshall hade inte skett under det gångna året. De 6,3 miljoner kr som avsatts för investeringen i en idrottshall fanns fortfarande kvar i den nya investeringsbudget som skulle röstas igenom. Det rådde emellertid delade meningar inom de olika partierna. Mot bakgrund av konsultens rekommendationer och kommunens ansträngda ekonomi fanns det politiker som ville stryka den budgeterade kostna- 
den för en sporthall från investeringsbudgeten. Investeringsbudgeten röstades emellertid igenom och de budgeterade medlen för en idrottshall fanns kvar (KF I5 december 2003). Att ha medel budgeterade för en investering är emellertid inte det samma som att genomföra den. Kommunfullmäktige hade röstat för att godkänna en investeringsbudget som gällde hela kommunens verksamhet under 2004. Något politiskt beslut för att faktiskt genomföra den investering som avsåg byggandet av en idrottshall i Hovmantorp under 2004 fanns däremot inte.

\section{Interaktion i ett semiorganiserat fält. Nya mobiliseringsförsök hos HGoIF hösten 2003-våren $2004^{4}$}

Under det att "stålbadsanalysen" pågick under 2003 fortsatte HGoIF att engagera sig i frågan. De planerade hur de själva, med hjälp av företagare och ideella krafter i närområdet, skulle kunna bygga en idrottshall om de fick tillgång till de medel som fanns avsatta i investeringsbudgeten. En grupp engagerade individer i föreningen gjorde studiebesök på andra platser där hallar byggts med hjälp av frivilliga krafter. En av de engagerade var förälder till en innebandyspelande pojke, de övriga var aktiva i föreningen på olika sätt.

Under slutet av 2003 blev det emellertid uppenbart att planerna på en idrottsanläggning tycktes ha gått i stå inom kommunen och att det rådde politisk splittring i frågan. Det fanns inte tillräcklig politisk enighet för att driva igenom "projekt idrottshall" i Hovmantorp. Föreningen hade alltså bidragit till att skapa en inlåst ekonomisk resurs inom en etablerad organisations gränser, men den kunde inte göra den tillgänglig för sin egen organisation (Ahrne \& Papakostas 2002: 107).

I den här situationen kontaktade ordföranden i idrottsföreningen den tidigare nämnda föräldern. Men föräldern kontaktades i sin egenskap av ordförande i den lokala företagarföreningen Abbakuse. Det var med andra ord en representant för en organisation som kontaktade en representant för en annan organisation även om individerna var de samma. Ordföranden i idrottsföreningen överlämnade en formell skrivelse där

4. Beskrivningen av skeendet under denna rubrik bygger på intervjuer med IPI-7. 
idrottsföreningen bad ortens företagarförening att fortsätta driva frågan om en sporthall i Hovmantorp. I skrivelsen förklarade HGoIF att de inte ansåg det möjligt att driva projektet längre, att det nu behövdes andra krafter för att ta det vidare (HGoIF, dokument 8). Interaktionen mellan de båda individerna var nu inbäddad i och transformerad till en mellanorganisatorisk interaktion, figur 3.I.

Figur 3.I. Idrottsföreningen HGoIF försöker överlämna idén till företagarföreningen Abbakuse

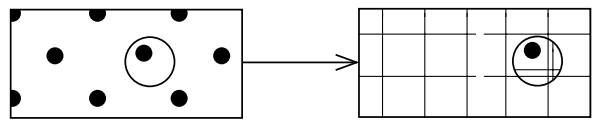

HGoIF
Företagarföreningen Abbakuse = Förälder och företagar-
föreningens ordförande = Ordföranden i idrotts-
föreningen

Ordföranden i den lokala företagarföreningen, det vill säga den innebandyspelande pojkens förälder, lyckades emellertid inte övertyga företagarföreningens medlemmar att ta över ansvaret för projektet. Ordföranden mobiliserade då ett antal lokala företagare att engagera sig privat i frågan. Dessa fortsatte tillsamman med idrottsföreningen att engagera sig i projektet. I och med det förändras projektet analytiskt. Det lämnade en organisation, idrottsföreningen, men det trädde inte in i en annan organisation. I det här skedet drevs projektet i ett semiorganisatoriskt fält där några av individerna utgjorde idrottsföreningens representanter och de andra utgjordes av enskilda företagare. Gruppen hade kompletterats med fyra företagare samt föreståndaren för Hovmantorps Folkets hus. När projektet lämnade HGoIF fördes diskussioner om hur man skulle kunna mobilisera ett brett stöd för projektet i Hovmantorp. Tankegångarna handlade om att det borde markeras att det inte var fråga om att bygga en idrottshall till en enda förening. Hallen kanske därför borde ligga mera centralt i samhället, till exempel i anslutning till Folkets

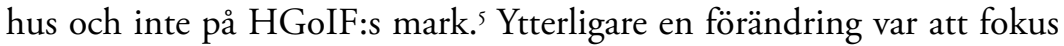
flyttades från idrottsföreningen till ordföranden för den lokala företa-

5. Denna aspekt behandlas utförligare i kapitel 4 i Jessica Hansens avhandling. 
garföreningen, det vill säga föräldern. Det var kring honom de andra grupperade sig.

Gruppens centrum flyttades från idrottsföreningen till företagarföreningens ordförande. Idrottsföreningen förlorade emellertid inte sitt inflytande. Dess medlemmar fortsatte att engagera sig även om projektet inte längre befann sig inom denna organisations gränser. Interaktionen mellan individerna skedde nu i ett semiorganiserat fält. Gruppens målsättning var att tillskansa sig den bundna ekonomiska resursen, det vill säga de 6,3 miljoner $\mathrm{kr}$ som fanns budgeterade i den kommunala investeringsbudgeten för att kunna bygga en idrottshall. I det här skedet hade de första tankarna väckts om att projektet behövde breddas till att handla om mer än en idrottshall.

Vad det var som skulle byggas, förändrades under processens gång. Det har omväxlande och i perioder talats om idrottshall, bollhall och allaktivitetshall. Det ursprungliga projektet benämndes idrottshall. När HGoIF talade om det benämndes det bollhall. När projektet flyttades ut ifrån HGoIF blev det med tiden en allaktivitetshall. I just detta skede talades det om en bollhall, men tankarna om att det snarare var fråga om en allaktivitetshall hade väckts. ${ }^{6}$

\section{Interaktion utanför organisationer. Informell grupp april 2004}

Organiseringen kring idén tog ytterligare ett steg då gruppen som beskrivits ovan utlyste ett offentligt möte i Hovmantorps Folkets hus den 29 april 2004 (Allhall i Hovet, dokument I). Mötets syfte var att sprida information om projektet och att skapa stöd hos allmänheten för det. Det kom ca 30 personer till mötet. De flesta av dem var engagerade i en ideell förening av något slag. Ordföranden för företagarföreningen höll i mötet. Han presenterade sig emellertid som privatperson och inte som representant för en organisation. Han refererade också till de andra i gruppen i termer av ett antal engagerade samhällsinvånare. Publiken informerades om de ekonomiska medlen i kommunens investerings-

6. Dessa glidningar behandlas närmare i kapitel 4 i Jessica Hansens avhandling. 
budget och om att andra mindre samhällen byggt idrottshallar med hjälp av lokala företag och ideella arbetsinsatser. Genom att presentera sig på detta sätt ville gruppen göra idén om en allaktivitetshall till en samhällsangelägenhet. Den ville bredda engagemanget för att få ett starkare stöd för sin idé. Sju individer på mötet deklarerade att de var intresserade av att arbeta med projektet. Den ursprungliga gruppen utökades därmed med personer från andra föreningar. Två av dessa tillhörde två olika gymnastikföreningar medan en person var engagerad i bouleklubben. Det förblev emellertid ett projekt som drevs utanför de formella organisationerna. Figur 3.2 visar hur gruppen utökades.

\section{Figur 3.2. Informell grupp utanför organisationer}

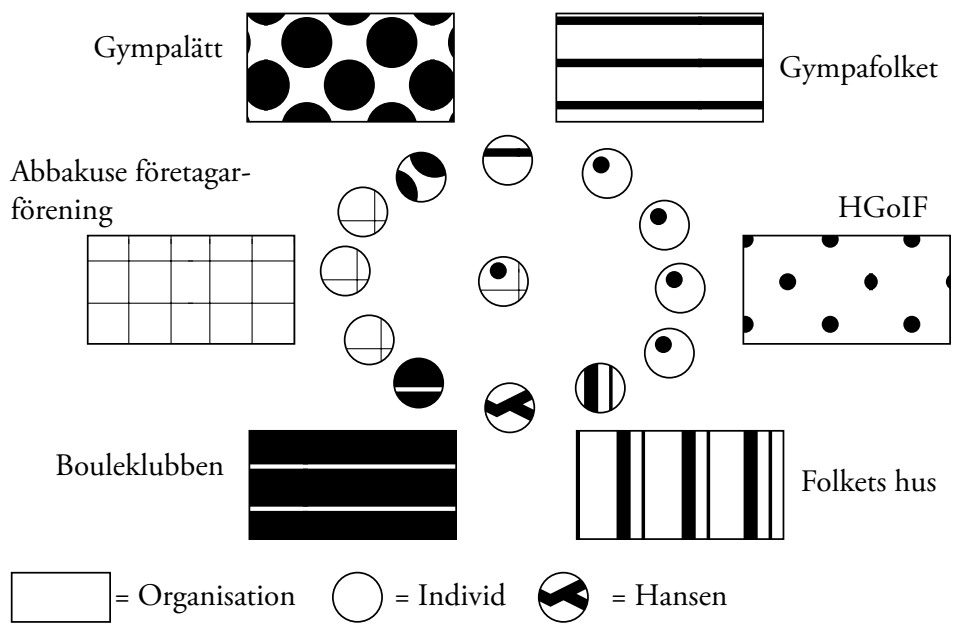

Före det offentliga mötet figurerade de två organisationerna Abbakuse och HGoIF i bakgrunden och i någon mån också Folkets hus. Efter det offentliga mötet tillkom de två gymnastikföreningarna och bouleklubben. Två av de företagare som ursprungligen engagerat sig i projektet drog sig tillbaka och en annan tillkom. Det tillkom även en person (Hansen) som inte hade någon organisatorisk bakgrund i Hovmantorp. Två av representanterna från HGoIF drog sig också tillbaka i detta skede och två andra tillkom (JH/OB 29 april 2004). 


\section{Interaktion inom en ny organisation. Föreningen Allhall i Hovet maj 2004}

På sitt första möte enades den informella gruppen om att bilda en ideell förening. Gruppen döpte organisationen till Allhall i Hovet. Den nya föreningen organiserade sitt arbete $\mathrm{i}$ en styrelse och fyra arbetsgrupper. Arbetsgrupperna bestod av: en marknadsföringsgrupp som hade i uppgift att skapa en hemsida, ta fram informationsmaterial och göra reklam för projektet; en aktivitetsgrupp som hade i uppgift att ta reda på vilka aktiviteter allmänheten ville ha i en allaktivitetshall; en ekonomigrupp som skulle skapa de ekonomiska förutsättningarna för projektet; samt en byggrupp som skulle ta fram ritningar och ansvara för själva byggprocessen (JH/OB 3 maj 2004).

När den informella gruppen blev en ideell förening ändrade den i analytisk mening återigen karaktär. Nyckelpersonen, ordföranden i företagarföreningen, drog sig tillbaka och en styrelse tog över ansvaret för att driva idén. I det här skedet var den åter tillbaka i en formell organisation. På vilket sätt skilde sig den här organisationen ifrån den som ursprungligen drev idén, det vill säga HGoIF? För det första bestod den nya organisationens verksamhet uteslutande av att mobilisera tillräckligt med resurser för att möjliggöra byggandet av en allaktivitetshall i Hovmantorp. För det andra kunde den inte förknippas med en enskild förenings specifika intressen. Ingen av de redan existerande föreningarna i Hovmantorp ägde idén. Att stödja den innebar inte längre att stödja en enskild förenings verksamhet. Den konstellation av individer som drev den nya organisationen representerade en bredare bas i lokalsamhället än vad HGoIF gjorde. Den nya föreningen var fri från en egen historia på orten och den hade därför en potential att undvika gamla låsningar och spänningar mellan olika organisationer. Visserligen hade de ingående medlemmarna i den nybildade föreningen olika organisatoriska rötter på orten och var i den bemärkelsen inte fria. Den nya organisationen hade emellertid ingen historia på orten. Den hade därför större potential att undvika låsningar än vad de befintliga organisationerna hade.

Föreningens ambition var att mobilisera en så stark opinion för idén att det blev möjligt att ta i anspråk den ekonomiska resurs som fanns 
bunden i den kommunala investeringsbudgeten. Den skulle också mobilisera tillräckligt stöd för att kunna finansiera mellanskillnaden mellan 6 miljoner $\mathrm{kr}$ och allaktivitetshallens verkliga kostnad. Det skulle ske genom andelsförsäljning, materialrabatter från företag, ansökningar ur diverse fonder och genom ideella arbetsinsatser.

\section{Interaktion mellan organisationer. Individer kopplar samman organisationer maj 2004-november 2005}

Föreningen strävade efter att få stöd från så många organisationer som möjligt. Aktivitetsgruppen kontaktade samtliga föreningar i Lessebo kommun, I42 stycken, varav 34 var baserade i Hovmantorp. De inbjöds att diskutera hur de skulle vilja använda en allaktivitetshall. Det kom att bli I2 föreningar i Hovmantorp och en kommunövergripande förening som aktivt bidrog med önskemål om hur de ville utforma lokalerna i allaktivitetshallen.

\section{Individers överlappande organisatoriska tillhörigheter}

Föreningen Allhall i Hovet höll i regel möten en gång i veckan 20042007 med ett antal veckors uppehåll under semestertid. På dessa möten deltog styrelsen och arbetsgrupperna och ibland också andra individer som var intresserade. Över tid har individer kommit och gått i projektet. Vissa lämnade det i perioder för att sedan återkomma. Andra lämnade det för gott men fortsatte att stödja projektet som sådant. Under arbetet med projektet blev deltagarnas koppling till andra lokala organisationer efterhand allt mer synliga. Föreningen Allhall i Hovet var dock inte en paraplyorganisation med andra organisationer som medlemmar. För det första hade föreningen såväl individer som organisationer som medlemmar. För det andra var de individer som fanns i Allhall i Hovets styrelse och arbetsgrupper inte formellt utsedda representanter för några föreningar. Den enda förening som hade en representant i den meningen var Folketshusföreningen. Den hade en representant ifrån sin styrelse som förde en dialog med Allhall i Hovet. Övriga deltagare i Allhall i Hovet var mer eller mindre självutnämnda representanter för olika föreningar. I de flesta fall hade de flera organisatoriska tillhörigheter. 
Hur kan dessa självutnämnda representanter förstås? En stor del av individers aktiviteter kanaliseras genom organisationer (Ahrne \& Papakostas 2002). Även om individer deltog som individer i föreningen Allhall i Hovet så gjorde deras olika organisatoriska tillhörigheter dem till representanter för olika organisationer i en informell mening. De kunde inte delta som individer utan att föra med sig skilda organisatoriska tillhörigheter in i Allhall i Hovet.

De aktiva medlemmarna i Allhall i Hovet använde sina resurser i andra organisationer eller sina individuella relationer till individer med resurser i andra organisationer för att koppla samman dem med Allhall i Hovet. En av de aktiva medlemmarna var till exempel också aktiv i bouleklubben. Han diskuterade föreningens målsättning med medlemmar i bouleklubben och påpekade möjligheterna för klubben att dra nytta av en allaktivitetshall. Diskussionerna utmynnade i att bouleklubben formulerade ett förslag om vad de skulle vilja ha ut av en allaktivitetshall. De ville ha tillgång till boulebanor inomhus (Allhall $\mathrm{i}$ Hovet, dokument 2). Dessa önskemål införlivades i planerna för hur en allaktivitetshall skulle utformas. Därmed kom klubben att aktivt stödja föreningen Allhall i Hovet. Den överlappande organisatoriska tillhörigheten hos en av Allhall i Hovets medlemmar kopplade samman de båda organisationerna kring ett gemensamt intresse. En annan aktiv medlem besökte sina grannar och diskuterade Allhall i Hovet med dem. Dessa var aktiva medlemmar i dragkampföreningen. En diskussion initierades om hur de skulle vilja utveckla sin verksamhet i framtiden. Diskussionerna utmynnade i att dragkampsföreningen gjorde en skiss över hur en lokal lämplig för dragkampträning inomhus skulle kunna se ut. Skissen införlivades i planerna på hur en allaktivitetshall skulle utformas $(\mathrm{JH} /$ $\mathrm{OB}, 2 \mathrm{I}$ juni 2004). I och med detta hade en individ kopplat ytterligare en organisation till föreningen Allhall i Hovet. Denna gång skedde det genom en individs relationer till individer med positioner $i$ en annan organisation. På detta sätt har mobiliseringen av organisationer skett. Individer har använt sina överlappande organisatoriska tillhörigheter eller sina individuella kontakter med individer som i sin tur har haft positioner i andra organisationer för att koppla olika organisationer till Allhall i Hovet. 
De aktiva i Allhall i Hovet har också använt sig av varandras överlappande organisatoriska tillhörigheter för att skaffa sig information av olika slag. Under ett och samma möte kunde samma person uttala sig utifrån flera olika organisatoriska tillhörigheter. Ibland valde personen själv att dra fram någon av sina tillhörigheter i ljuset ibland var det de övriga deltagarna som gjorde det. Under ett av föreningens möten uttalade sig till exempel en av de aktiva i tur och ordning som ordförande för ett kommunalt fastighetsbolag och därefter som aktiv socialdemokrat. När han intog positionen som socialdemokrat var det på eget initiativ. Han ville då göra föreningen Allhall i Hovet uppmärksam på att det fanns medlemmar i partiet från andra delar av kommunen som motsatte sig att satsa de 6,3 miljoner kr som fanns i investeringsbudgeten på allhallsprojektet. En stund därefter diskuterades den blivande allaktivitetshallens uppvärmningssystem och kostnader i samband med detta. I denna diskussion vände sig de andra deltagarna till samma person i hans roll som ordförande i Lessebohus $\mathrm{AB}$. Han fick redogöra för hur långt planerna för utbyggnad av fjärrvärme framskridit, om det var något som Allhall i Hovet kunde ta med i beräkningen när de planerade för allaktivitetshallens energisystem och så vidare (JH/OB 8 juni 2005). Vid åter andra tillfällen har det varit hans tillhörighet till bouleklubben som varit framträdande då frågor som handlat om till exempel boulebanans beskaffenhet har avhandlats. De här skiftena mellan olika organisatoriska tillhörigheter pågick kontinuerligt vid föreningens sammankomster. De aktiva medlemmarna rörde sig mellan olika organisatoriska tillhörigheter i sin interaktion med varandra. De använde varandra som informationskällor, som uttolkare av olika organisationers ståndpunkter och uppfattningar i olika frågor och som kontaktpersoner när så behövdes.

\section{Interaktion mellan organisationer. Det organisatoriska fältet förändras maj 2004-november 2005}

Det har funnits några organisationer som haft tätare anknytning till Allhall i Hovet än andra. När dessa gjort gemensam sak med Allhall i Hovet så har det organisatoriska nätverket i Hovmantorp förändrats på ett 
sådant sätt att nätverken dels kopplat ihop idrott och kultur, dels gjort att de organisatoriska nätverken blivit vidare. Jag benämner dessa organisationer "kärnorganisationer". De utgörs av den lokala företagarföreningen Abbakuse, idrottsföreningen HGoIF samt Hovmantorps Folkets hus.

HGoIF var den organisation som från början väckte idén även om det då var i form av en idrottshall och senare bollhall. Den har varit knuten till Allhall i Hovet genom att aktiva innebandyledare suttit med i organisationens styrelse. Allhall i Hovets ordförande, vid den här tiden, var lagledare i ett av HGoIF:s innebandylag. Allhall i Hovets sekreterare var ledare för ett annat av HGoIF:s innebandylag. Ordföranden för innebandysektionen i HGoIF ingick under en tid i en av Allhall i Hovets arbetsgrupper.

Även Abbakuse företagarförening var tätt knutna till organisationen. Företagarföreningens ordförande var ledamot i Allhall i Hovets styrelse. Dess sekreterare var kassör. Ytterligare två ledamöter i företagarföreningen var ledamöter i Allhall i Hovets styrelse.

Folkets hus var nära förbundet med Allhall i Hovet till följd av den tänkta placeringen av allaktivitetshallen. Den skulle byggas i anslutning till Folkets hus och integreras fysiskt med denna byggnad. Folketshusföreningen var därför i allra högsta grad inblandad i och påverkad av organisationens verksamhet. Föreståndaren och ordföranden i Folkets hus turades om att i perioder närvara vid dess möten och rapportera tillbaka till sin egen styrelse. Det pågick också en löpande dialog kring diverse praktiska frågor mellan Allhall i Hovet och Folkets hus.

\section{Aktivt stöd och fränvaro av motstånd}

I lokalsamhället fanns det olika intressesfärer knutna till kärnorganisationerna. Dessa var grupperingar av organisationer som på ett eller annat sätt hyste ett intresse av att kärnorganisationerna nådde sin målsättning, eller åtminstone hyste tillräckligt med sympati med dem för att avstå ifrån att formera ett aktivt motstånd. Kärnorganisationerna utmärktes av att när deras intressen sammanföll kom en stor del av det organisatoriska fältet i Hovmantorp att enas kring detta. När Hovmantorps Folkets hus aktivt uttalade sitt stöd för projektet innebar det att de föreningar som idag har Folkets hus som bas för sina verksamheter också kunde 
vara sympatiskt inställda till projektet. Dessa organisationer utgjordes bland annat av teaterföreningarna, ABF och PRO. I Hovmantorp utövar de flesta av de föreningar som inte är idrottsanknutna sina aktiviteter i Folkets hus lokaler. Att koppla samman Folkets hus och Allhall i Hovets intressen innebar att flera organisationer kom att bli sympatiskt inställda till projektet eller att de åtminstone avstod ifrån att formera ett aktivt motstånd. Kopplingen mellan Allhall i Hovet och HGoIF med 800 medlemmar och en omfattande barn- och ungdomsverksamhet, innebar att många familjer i Hovmantorp sympatiserade med, eller åtminstone avstod från, att formera ett aktivt motstånd mot projektet. Att koppla samman dessa två dominerande föreningar på orten, HGoIF och Folkets hus, innebar att idrott och kultur fick ett gemensamt intresse. Ser man till företagarföreningen så har det i Hovmantorp, precis som på många andra mindre orter, traditionellt funnits starka band mellan de lokala företagen på orten och idrottsföreningen HGoIF (HGoIF, dokument 9; Haraldsson 2003: 60-87). Dessa band kom nu indirekt att utvidgas till att också omfatta kulturen. Kopplingen till den lokala företagarföreningen och de överlappande styrelsepositionerna innebar att det fanns öppna kanaler till det lokala näringslivet som också kom att gynna den kulturella sfären i Hovmantorp.

Kopplingen mellan de organisationer jag benämnt "kärnorganisationer" förändrade sammansättningen av det organisatoriska fältet i Hovmantorp. Genom dessa kopplingar utsträcktes organisationernas nätverk i det geografiska rummet och dess mobiliserande potential ökade. För att summera: då de organisationer jag har benämnt kärnorganisationer arbetade för en gemensam målsättning kunde en stor del av Hovmantorps övriga organisationer sluta upp kring detta intresse. Den interaktion som kopplade samman Hovmantorps organisationer har till stor del karaktäriserats av individers informella interaktion mellan organisationer. Under dessa omständigheter kunde ett mindre antal aktiva individer driva projektet framåt. Den 28 november 2005 nådde föreningen Allhall i Hovet ett viktigt delmål i sitt arbete då kommunfullmäktige i Lessebo kommun beslutade att investera 6 miljoner kr för byggnationen av en allaktivitetshall. Därmed hade en inlåst ekonomisk resurs frigjorts (Ahrne \& Papakostas 2002: 107). 
Figur 3.3. Det organisatoriska fältet i Hovmantorp $i$ november 2005 efter det att Allhall i Hovet bildats

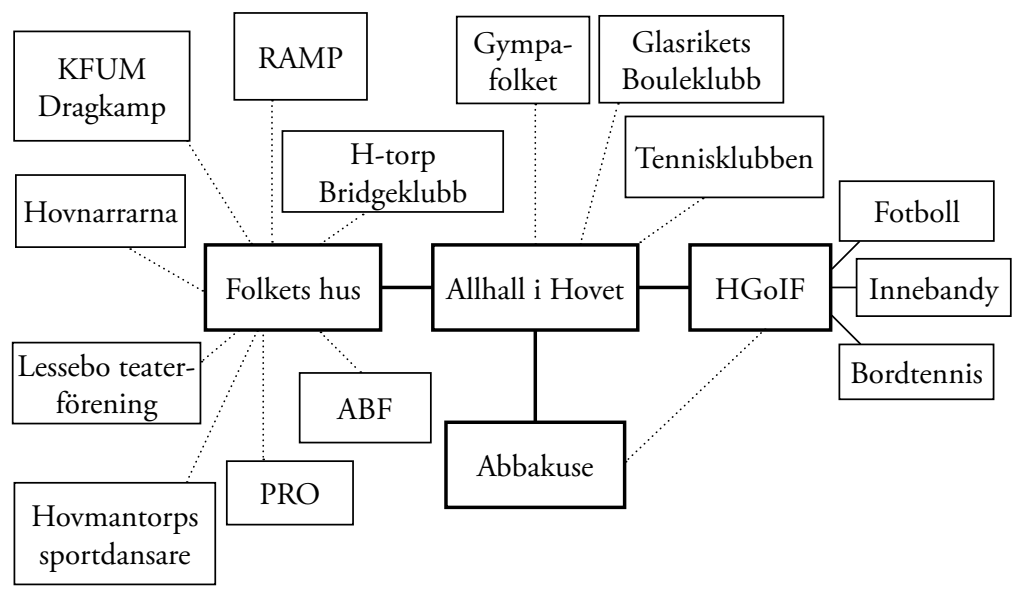

\section{Organisatoriska fält, figurationer, maktrelationer och interdependens}

En fråga återstår dock att besvara i det här kapitlet. Vad var det som gjorde att kommunen bestämde sig för att investera ekonomiskt $\mathrm{i}$ allhallsprojektet trots sin besvärliga ekonomiska situation? Ett sätt att antyda en förklaring är att föra in en maktdimension i analysen och återvända till frågan om vad det var som hände när organisationer kopplades samman i Hovmantorp. Nedan kommer jag att betrakta relationen mellan det lokalpolitiska fältet och det organisatoriska fältet i Hovmantorp som en figuration bestående av två olika organisatoriska fält och analysera hur interdependensen och maktrelationerna inom denna figuration ändrar karaktär över tid (Elias 1978). Hur ser det lokalpolitiska fältet i Lessebo ut? Lessebo kommun består, som tidigare nämnts, av fyra tätorter och dess omgivningar. De lokala politiska partierna består av medlemmar från dessa olika geografiska områden. Det finns alltså två dimensioner i det kommunala beslutsfattandet, en politisk och en geografisk.

Det lokalpolitiska fältet bestod av en rad olika organisationer som ingick i olika ömsesidiga relationer med och mot varandra. Inom de 
olika partierna fanns en geografisk dimension. Intressekonflikter kan med andra ord potentiellt uppstå såväl utifrån geografiska som partipolitiska dimensioner. Det lokalpolitiska fält som HGoIF strävade att utöva inflytande över bestod av en mängd organisatoriska konstellationer. När HGoIF försökte påverka sina lokala politiker att bygga en idrottshall i Hovmantorp skulle de i själva verket påverka ett helt lokalpolitiskt fält med en mängd olika inneboende intressen, konfliktlinjer och skilda prioriteringar som spände inom och över såväl partipolitiska som geografiska dimensioner. HGoIF är en organisation med många medlemmar (ca 800 stycken) och utgör i den bemärkelsen en betydelsefull organisation. Men föreningen skulle påverka ett lokalpolitiskt fält bestående av en rad olika organisationer som stod i olika ömsesidiga beroendeförhållanden inte bara till varandra utan också till intressen utanför det lokalpolitiska fältet som andra frivilliga, privata och offentliga organisationer. Även om det går att hävda att det råder ett visst ömsesidigt beroende mellan det lokalpolitiska fältet och HGoIF, utifrån det faktum att föreningen driver en omfattande barn- och ungdomsverksamhet och därmed utgör ett viktigt inslag för livskvaliteten i den folkrikaste av kommunens orter, så var inte beroendet ifrån kommunens sida av den arten att den omedelbart ansåg sig manad att bygga en idrottshall i Hovmantorp.

Figur 3.4 visar hur figurationen förändrades när Centerpartiet la en motion om att utreda behovet av en idrottshall i Hovmantorp under valåret 2002. Ett utspel ifrån majoritetspartiet Socialdemokraternas sida om gratis barnomsorg vändes emot dem själva under det att HGoIF mobiliserade sina medlemmar att skriva på stödlistor för en idrottshall i Hovmantorp samtidigt som det gjordes en serie reportage i Smålandsposten på temat "hellre idrottshall än gratis förskola". Under ett valår är det politiska fältet mer sårbart än annars. I det här skedet går det att tala om att det skedde någon form av mobilisering ifrån organisationen HGoIF:s sida. Mobiliseringen bestod av att samtidigt som denna organisation agerade fanns det en annan organisation inom det lokalpolitiska fältet som placerade frågan på den politiska dagordningen. Dessutom resulterade HGoIF:s mobilisering $\mathrm{i}$ att frågan blev föremål för offentlig debatt då den synliggjordes genom media. I detta skede går det att tala 
om att någon form av ömsesidigt beroende eller interdependens uppstår mellan det lokalpolitiska fältet och HGoIF.

\section{Figur 3.4. Figuration HGoIF, Smålandsposten och det lokalpolitiska fältet}
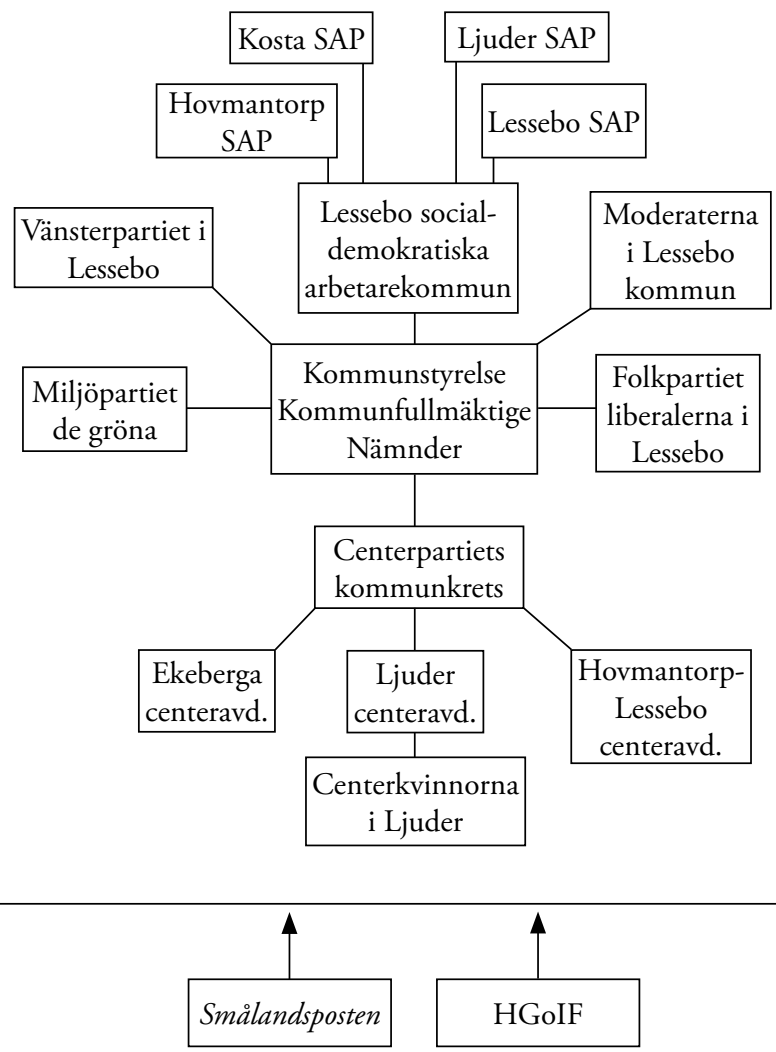

Enligt Elias (1978) uppstår en maktrelation när den ena parten inte har total kontroll over den andra. I sådana situationer uppstår någon form av maktspel. Men det faktum att en part inte har total kontroll over den andra innebär också att det i någon mån existerar ett ömsesidigt beroende mellan parterna. Det är denna omständighet som gör att en part 
sällan helt och hållet bestämmer vilken väg ett skeende tar. Intentioner och handlingar kommer alltid att brytas mot andra aktörer som den handlande är beroende av (Newton 2002: 529).

Den förändrade maktrelationen bestod av att det nu inte endast var HGoIF som var beroende av kommunpolitikernas makt att tilldela resurser. $\mathrm{Nu}$ fanns det också ett intresse hos majoritetspartiet Socialdemokraterna att hantera frågan om en idrottshall så att det inte skulle bli negativt för dem senare i valrörelsen. Det gick inte att nonchalera frågan, eftersom den indirekt satts på den politiska dagordningen av HGoIF via Centerpartiet och Smålandsposten. Mobiliseringen räckte emellertid inte hela vägen vilket redogjorts för tidigare i kapitlet. Den räckte däremot till att skapa en bunden ekonomisk resurs i Lessebo kommuns investeringsbudget.

Hur såg då den figuration ut som tog form under det att det organisatoriska nätverket bildades i Hovmantorp? Det är inte längre fråga om en enskild ortsspecifik organisation som försöker påverka ett lokalpolitiskt fält. Det går nu i stället att tala om ett nytt fält bestående av ett lokalsamhälles organisationer som strävar efter att utöva inflytande över det existerande lokalpolitiska fältet. Det nya fältet består av lokalsamhällets organisationer som samordnats kring ett och samma intresse och mål. Dessa organisationers medlemmar omfattar en stor del av de röstberättigade personerna i kommunens största ort. $\mathrm{Nu}$ är det inte längre en enskild organisation som försöker påverka det politiska fältet. $N u$ är det ett fält som försöker påverka ett annat fält. Det råder ett ömsesidigt beroende mellan det organisatoriska fältet i Hovmantorp och det lokalpolitiska fältet i Lessebo kommun.

Det var utifrån denna position som Lessebo kommun agerade när kommunfullmäktige den 28 november 2005 röstade för att investera 6 miljoner kr i föreningen Allhall i Hovets byggprojekt.

\section{Uppsummerande diskussion}

I det här kapitlet som handlar om en idés organisatoriska framväxt har jag visat vilka vägar individers interaktion tagit i förhållande till den organisatoriska kontexten under det att en idé vuxit fram och ett projekt konkretiserats. Jag har dessutom visat hur dessa olika sätt att interagera i för- 
hållande till omgivningens organisationer resulterat $\mathrm{i}$ att konstellationer av individer sammanförts på ett sådant sätt att dessa, i ett senare skede, bidragit till att åstadkomma sammankopplingar mellan vissa kärnorganisationer. Omkring dessa kärnorganisationer fanns åter andra organisationer grupperade. Då kärnorganisationerna från olika intressesfärer i lokalsamhället kopplades samman, länkades tidigare åtskilda organisatoriska sfärer ihop och mobiliseringspotentialen ökade. Skeendet var alltså följande: Först länkades ett antal individer samman. I nästa skede länkades organisationer samman utifrån enskilda individers positioner i dessa. När detta skedde länkades skilda intressesfärer ihop.

Genom att skildra idéns organisatoriska framväxt med hjälp av Ahrnes (1994) diskussioner om interaktioners väg inom, mellan och utanför organisationer har projektets väg från idé till mellanorganisatoriskt nätverk synliggjorts. Det har också synliggjort aktörerna i processen, det vill säga individer med överlappande organisatoriska tillhörigheter. Genom att analysera hur interdependensen mellan det lokalpolitiska fältet och de organisatoriska intressen som försökt driva idén har förändrats under tre olika mobiliseringsförsök, har en maktdimension lagts till analysen för att ge ett förslag på hur det går att förstå kommunens agerande i frågan.

Tilly (1985: 727-73I) menar att modeller om hur mobilisering går till grovt kan delas in i två sätt att resonera. Den första varianten som han benämner "cumulative reasoning" utgår ifrån att enskilda individer som var för sig hyser ett specifikt intresse mer eller mindre omedvetet söker sig till andra som de kan dela sina intressen med. Under denna process utvecklas ett gemensamt medvetande vilket i sin tur ligger till grund för kollektiv handling i syfte att främja det gemensamma intresset i fråga. I centrum för analysen står ofta framväxten av det gemensamma medvetandet. Den andra varianten, som han benämner "constructive reasoning", tar som utgångspunkt att det finns en social struktur av något slag som binder samman människor. Under en mobilisering blir dessa band fler, starkare och förändrade under det att mängder av kontakter tas och interaktioner sker mellan individer. Det är emellertid de redan existerande banden mellan en uppsättning individer som utgör basen $\mathrm{i}$ en mobiliseringsprocess. Detta senare resonemang har synliggjorts i 
det här kapitlet. Det är mycket tydligt hur individer mobiliserar stöd i redan existerande nätverk och hur de grupperar och omgrupperar sig för att åstadkomma starkare mobilisering. Men resonemanget har också utvecklats genom att organiseringens och organisationernas betydelse för mobiliseringen lyfts fram. Jag har identifierat det handlingsutrymme som skapats på kommunal nivå då investeringsmedel avsattes i en kommunal budget. Samtidigt har jag följt individers interaktion, hur de i syfte att mobilisera stöd för sin sak har använt befintliga relationer och positioner för att formera en ny organisation. Denna organisation har i ett senare skede knutit andra organisationer till sig. Dessa aspekter har synliggjorts genom att använda Ahrnes (1994) typologi över interaktionens väg i förhållande till omgivningens organisationer. Jag har dock inte gett någon förklaring till varför föreningen kunde mobilisera en så stark lokal opinion för sitt projekt. Den frågan besvaras i nästa kapitel ${ }^{7}$ där projektets mobilisering av stöd för sin sak står i centrum.

\section{Referenser}

\section{Muntliga källor}

IPI styrelsemedlem i Hovmantorps GoIF, intervju 5 juli 2004, november 2005.

IP2 styrelsemedlem i Hovmantorps GoIF, intervju 5 juli 2004.

$\mathrm{IP}_{3}$ styrelsemedlem Allhall i Hovet ideell förening, intervju 24 augusti 2004, oktober 2005.

$\mathrm{IP}_{4}$ styrelsemedlem Allhall i Hovets ideell förening, intervju I september 2004.

IP5 styrelsemedlem Allhall i Hovets ideell förening, intervju II september 2004, oktober 2005, 23 juni 2008.

IP6 styrelsemedlem Allhall i Hovets ideell förening, intervju 9 augusti 2004, 25 april 2005, 23 juni 2008.

IP7 styrelsemedlem Allhall i Hovets ekonomisk förening, intervju I4 november 2005.

\section{Otryckta källor och okatalogiserat småtryck}

Allhall i Hovet, dokument I-2 (av Io i avhandlingen): I. Allaktivitetshall i Hovmantorp. Inbjudan till stormöte på Folkets hus 29 april 2004; 2. Brev från Glasriket Bouleklubb, juli 2004.

HGoIF (Hovmantorps gymnastik och idrottsförening), dokument 8-9 (av 9 i avhandlingen): 8. Brev till Abbakuse från HGoIF, 2003; 9. Verksamhetsberättelse, 2004, 2006.

JH/OB: Jessica Hansson, Observationsanteckningar april 2004-januari 2006.

7. Kapitel 4 i Jessica Hansens avhandling. 


\section{Kommunala handlingar}

AU - Kommunstyrelsens arbetsutskott, Lessebo kommun, protokoll I april 2003.

Dnr 2002.170-82. Motion angående lokaler till fritidsverksambet $i$ Hovmantorp. Centerpartiet, 22 april 2002.

Framtidsstrategi för Lessebo kommun. En strategi och övergripande mål för år 2010. Remissutgåva, Kommunledningskontoret, is juni 2000.

KF - Kommunfullmäktige, Lessebo kommun, protokoll: 25 november 2002; I5 december 2003; 28 november 2005 .

KS - Kommunstyrelsen, Lessebo kommun, protokoll: Io juni 2003; 2 december 2003.

Plan för framtida utbyggnad av idrottsanläggningar. Kommunledningskontoret Lessebo kommun, 22 november 2002.

SN - Socialnämnden, Lessebo kommun, protokoll 27 augusti 2003.

Yttrande till Kommunstyrelsen över centerpartiets motion angående lokaler till fritidsverksamhet $i$ Hovmantorp, II oktober 2002.

\section{Dagspress}

Smålandsposten, Gratis barnomsorg. Socialdemokraternas vallöfte i Lessebo. Robert Owen, 23 augusti 2002.

—, Många i Hovmantorp föredrar idrottshallar framför fri barnomsorg. Anders Karlsson, 5 september 2002 .

—, Är det gratis barnomsorg, fler idrottshallar eller något annat som kan få kommunen att växa? Anders Karlsson, 6 september 2002.

—, Nya hallar inte dyrare än fri barnomsorg. Anders Karlsson, II september 2002.

—, Idrottshallar hett ämne i valdebatten. Anders Karlsson, I2 september 2002.

—, Många namn på sporthallslistan. Sif Erlandsson, 24 september 2002.

—, Löften om hallsatsningar. Snabbutredning skall tillsättas. Anders Karlsson, 25 september 2002 .

\section{Litteratur}

Ahrne, G. (1994) Social Organizations. Interaction Inside, Outside and Between Organizations. London: Sage.

Ahrne, G. \& Papakostas, A. (2002) Organisationer, sambälle och globalisering. Tröghetens mekanismer och förnyelsens förutsättningar. Lund: Studentlitteratur.

Elias, N. (1978) What is Sociology? London: Hutchinson.

Haraldsson, K. (2003) Idrott och företagande. I: A. Götlind, E. Bergström, K. Haraldsson, Eldsjälar, nätverk och lokal gemenskap. Studier kring föreningsliv och företagande $i$ Mora, Leksand, Edsbyn och Östervåla, s. 6o-87. Falun: Dalarnas forskningsråd.

Newton, T. (2002) Creating the New Ecological Order? Elias and Actor-Network Theory. Academy of Management Review, vol. 27, nr 4, s. 523-540. DoI: http://dx.doi.org/I0.5465/AMR.2002.7566046

Tilly, C. (1985) Models and Realities of Popular Collective Action. Social Research, vol. 52, nr 4, s. 717-747. 


\section{Jessica Hansen}

\section{"Så fixade vi Allhallen"}

Resursmobilisering och

organisationsförtätning i ett

lokalsamhälle

Arkiv förlag 2011, mjukband, 248 sidor

TILL DET

LOKALAS

CIVILSAMHÄLLeT

I DEN URBANA

PERIFERIN

FÖRSVAR

LISA KINGS

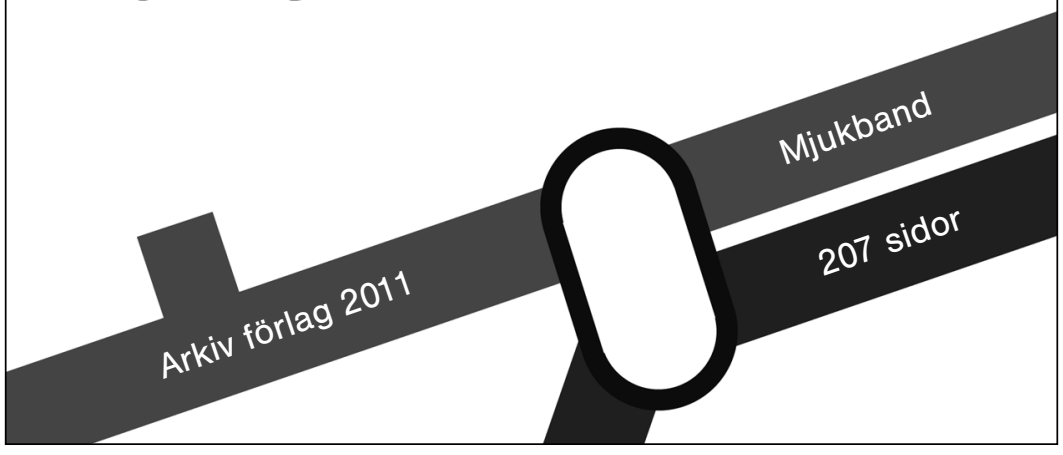

»Läs mer om böckerna på www.arkiv.nu« 